\title{
Unexpected Long Survival in Primary Malignant Melanoma of the Male Urethra
}

\author{
Evi Comploj ${ }^{\mathrm{a}}$ Salvatore Palermo ${ }^{\mathrm{a}}$ Emanuela Trenti \\ Michele Lodde ${ }^{a}$ Christine Mian $^{b}$ Rodolfo Carella ${ }^{b}$ \\ Armin Pycha \\ Departments of aUrology and ${ }^{\mathrm{b} P a t h o l o g y, ~ G e n e r a l ~ H o s p i t a l ~ o f ~ B o l z a n o, ~ B o l z a n o, ~}$ \\ Italy
}

\section{Key Words}

Malignant melanoma $\cdot$ Male urethra

\begin{abstract}
A case of primary malignant melanoma of the urethra in a 60-year-old male is presented. Despite multiple adverse prognostic factors and against expectations, after a follow-up of 5.5 years he is still alive.
\end{abstract}

\section{Introduction}

Primary malignant melanoma of the urethra is rare, representing less than $1 \%$ of all melanomas $[1,2]$, which means that it is often misdiagnosed and treatment can be delayed. Given its poor prognosis, early diagnosis is essential, and clinicians need to include it in their differential diagnosis when working up a patient with genitourinary complaints.

A working knowledge of the varied presentations associated with primary urethral melanoma as well as its histopathological features is an important component to early diagnosis and effective treatment. Many adverse prognostic factors exist such as age $\geq 60$ years, thickness $\geq 3.5 \mathrm{~mm}$, ulceration and diameter $\geq 15 \mathrm{~mm}[3,4]$. However, the presence or absence of lymph node metastasis is the most significant prognostic factor for survival, as survival rates are approximately halved by the presence of nodal metastasis $[2,4]$.

Individual management according to the clinical presentation has to be based on extrapolation of evidence for other melanoma treatments. Due to the low occurrence of urethral melanoma, the optimum therapy has not been established in the urological field, and surgery remains the mainstay of primary therapy; adjuvant local-regional and systemic therapies are needed [5-7]. 


\begin{tabular}{l|l|l|l} 
Case Reports $h$ & Case Rep Dermatol 2009;1:93-99 & Published online: November 20, 2009 & $\begin{array}{l}\text { ○ 2009 S. Karger AG, Basel } \\
\text { ISSN 1662-6567 } \\
\text { www.karger.com/cde }\end{array}$ \\
\hline
\end{tabular}

\section{Case Report}

A 60-year-old man was admitted to our institution in March 2004 complaining of persistent urethral discharge and induration in the distal urethra.

According to the patient's history, there was a continuous urethral discharge, predominantly after sexual intercourse, known since September 2003. At that time he was empirically treated for prostatitis with Permixon ${ }^{\circledR}$ (a compound lipid extract from the fruit of the American dwarf palm tree, Serenoa repens) and Nimesulid (non-steroidal anti-inflammatory drug). Subsequently, the patient was lost for follow-up. Anamnestically, he drank one liter of wine and smoked half a package of cigarettes per day.

In March 2004, a smear-test of the urethra was negative and cystourethroscopy revealed red, slightly bleeding lesions in the distal urethra involving the colliculus seminalis. Antibiotic therapy (ciprofloxacin $250 \mathrm{mg}$ orally twice a day for 12 days) and biopsy were recommended, which were declined by the patient.

Again he failed to attend follow-up appointments until 6 months later. At that time (in September 2004), he was willing to undergo a transurethral biopsy because of increasing symptoms.

Histopathological examination of the biopsy specimens revealed a solid, poorly differentiated neoplasia with large pleomorphic, fusiform and anaplastic cells, which were high-grade according to the WHO's classification and highly suspicious for malignant melanoma. The diagnosis was supported by immunohistochemical staining with a marker for melanoma (anti-Vimentin+, ProteinS-100+, HMB45+, MelanA+; AE1/AE3+, CD20+). Atypical pigmented melanocytic cells were also noted in urinary cytologic samples.

The metastatic workup, including physical examination, PET total body scan, total body CT-scan and bone scintigraphy showed palpable bilateral clinically pathological inguinal lymph nodes $(2.5 \times$ $2 \mathrm{~cm}$ in diameter, round), with some lymph nodes in the mediastinum (pretracheal and near the bifurcation of the trachea) and bilateral axillae.

In October 2004, a partial penectomy and urethrectomy (fig. 1) with negative surgical margins and a superficial inguinal lymph node dissection were performed. The final pathologic examination revealed a malignant ulcerated pigmented melanoma of the urethra with polyploidy solid pattern growth, intramucosal component and necrotic areas. Microscopically, it is formed of epitheloid, spindle, pleomorphic and anaplastic cells (MelanA+; HMB-45+; ProteinS-100+; Ki67/Mib1+ >20\%) (fig. 2) infiltrating the subepithelial connective tissue and focally the corpus spongiosum. Areas of regression were not observed. Neoangiogenesis and vascular neoplastic invasion are present (CD34+), as bilateral metastatic disease in inguinal lymph nodes: pTMN sec WHO: pT2 N2 Mx Gx R0 V1 (Staging D sec. Levine [Cancer 1980]).

A PET-scan revealed higher metabolic activity in the left inguinal region, and the patient was referred to a tertiary referral center for deep bilateral ilioinguinal, external iliac and obturator lymph node dissection in December 2004. One in 10 ilioinguinal lymph nodes showed metastatic disease involving the lymph node capsule, and 9 iliac and obturator lymph nodes showed reactive changes on the left side. On the right side, 13 ilioinguinal lymph nodes and 6 external iliac lymph nodes showed reactive changes. Postoperative complications included wound infection and chronic lymphedema, which were treated with antibiotics and lymph drainage therapy.

A PET-scan in April 2005 showed a high activity in the liver, raising suspicion of hepatic metastatic disease in segment VIII. This was confirmed by ultrasonographic examination and CT-scan (diameter of $4.6 \times 3.8 \times 4.5 \mathrm{~cm})$.

Cystourethroscopy was performed in May 2005 because of a weak urinary stream and showed an urethral recurrence situated in the distal part of the urethra. The patient underwent distal urethral resection of the lesion, which was histologically a relapse of the primary melanoma that was confined to the mucosa.

Subsequently, the patient underwent 6 cycles of carboplatin (CDDP $75 \mathrm{mg} / \mathrm{m}^{2}$ ) and deticene (DTC $800 \mathrm{mg} / \mathrm{m}^{2}$ ), which were well tolerated. The CT-scan that was repeated in July 2005 showed a reduction in the diameter of the metastasis in the liver $(1.3 \mathrm{~cm}$ vs. $4.6 \mathrm{~cm}$ in April), and it also showed a diffuse swelling of the dermis and subdermis in the inguinal region, which had not been visible at the previous CT.

Until March 2006, repeated abdominal ultrasonographic examinations were performed with unchanged findings in the liver. In the additional follow-up in June 2006, cerebral metastases in the left 


\begin{tabular}{l|l|l|l} 
Case Reports in & $\begin{array}{l}\text { Case Rep Dermatol 2009;1:93-99 } \\
\text { D01: } 10.1159 / 000256663\end{array}$ & Published online: November 20, 2009 & $\begin{array}{l}\text { @ 2009 S. Karger AG, Basel } \\
\text { ISSN 1662-6567 } \\
\text { www.karger.com/cde }\end{array}$ \\
\hline
\end{tabular}

parietal lobe (3 lesions with a diameter of 3-10 $\mathrm{mm}$ ) were found in the cerebral CT-scan and confirmed in the cerebral magnetic resonance imaging (MRI); the patient underwent chemotherapy with fotemustine $\left(100 \mathrm{mg} / \mathrm{m}^{2}\right)$ every 3 weeks until May 2007.

A control MRI in January 2007 showed a reduction in diameter of the cerebral metastasis. The CT-scan in October 2007 showed a reduction in diameter of the liver metastasis from $1.3 \mathrm{~cm}$ to $4 \mathrm{~mm}$. Ultrasound of the abdomen in March 2009 presented a suspicious lesion in the pancreas that was not confirmed in an abdominal MRI.

Since August 2009, the patient is just under conservative control. The patient is still alive (65 months after diagnosis) and is in good condition without signs of recurrence (follow-up by PET-CT in May 2009). Fig. 3 shows his external genitalia in August 2009.

\section{Discussion}

Primary malignant melanomas of the genitourinary system are rare, representing less than $1 \%$ of all melanomas $[1,2]$. Regarding urethral melanoma, mucosal sites are known to be associated with aggressive behavior, and from the onset of symptoms to the patient's seeking medical care, there is often a considerable delay [8]. Therefore, biopsy of all pigmented urethral lesions is recommended [2].

The urethra, especially the distal urethra, including fossa navicularis and urethral meatus, is the most common location of melanomas of the urinary tract, and about $30 \%$ of patients already have metastasis at the time of diagnosis [7] and have reached dangerous limits (e.g., depth of invasion or thickness at the time of diagnosis) [9]. Adverse prognostic factors are known, such as thickness (significant cutoff $\geq 3.5 \mathrm{~mm}$ ), ulceration and diameter (significant cutoff $\geq 15 \mathrm{~mm}$ ) $[3,4]$.

Cancers of the anterior urethra preferentially drain into superficial inguinal lymph nodes. Those of the posterior urethra generally drain into pelvic lymphatic channels [7]. However, the presence or absence of lymph node metastasis is the most significant prognostic factor for survival, as survival rates are approximately halved by the presence of nodal metastasis $[2,4]$.

The prognosis of malignant melanoma of the urethra is poor (2-year-survival is about $63 \%$ and 5-year-survival is $31 \%$ [3]) because of delayed diagnosis and treatment initiation.

Because of the low occurrence of malignant melanoma in the urethra, no therapy has been established in the urologic field. Prevention of disease progression by surgery alone is not successful and requires effective postoperative adjuvant therapy $[6,10]$, such as lymph node dissection $[2,11]$, immunochemotherapy $[12,13]$ or adjuvant radiotherapy. 
Table 1. Synopsis

\begin{tabular}{|c|c|c|c|c|}
\hline Date & Symptoms & Investigation & Findings & Treatment \\
\hline $\begin{array}{l}\text { 09/2003 } \\
\text { (practitioner) }\end{array}$ & $\begin{array}{l}\text { Urethral discharge } \\
\text { after sexual } \\
\text { intercourse }\end{array}$ & $\begin{array}{l}\text { Ultrasound } \\
\text { Urine examination }\end{array}$ & Prostatitis & Antibiotic therapy \\
\hline $\begin{array}{l}03 / 2004 \\
\text { (in our } \\
\text { institution) }\end{array}$ & $\begin{array}{l}\text { Urethral discharge } \\
\text { Urethral induration }\end{array}$ & $\begin{array}{l}\text { Cystourethroscopy } \\
\text { Smear test (negative) }\end{array}$ & $\begin{array}{l}\text { Slightly bleeding lesions in } \\
\text { the distal urethra involving } \\
\text { the colliculus seminalis }\end{array}$ & $\begin{array}{l}\text { Recommended biopsy } \\
\text { and antibiotic therapy }\end{array}$ \\
\hline $09 / 2004$ & $\begin{array}{l}\text { Urethral discharge } \\
\text { Urethral induration }\end{array}$ & $\begin{array}{l}\text { Urethral biopsy } \\
\text { Cytology }\end{array}$ & $\begin{array}{l}\text { Suspicious for malignant } \\
\text { melanoma } \\
\text { Atypical cells in cytologic } \\
\text { samples }\end{array}$ & $\begin{array}{l}\text { Recommended } \\
\text { penectomy and } \\
\text { urethrectomy }\end{array}$ \\
\hline $09 / 2004$ & & $\begin{array}{l}\text { PET total body } \\
\text { Total body CT-scan } \\
\text { Bone scintigraphy }\end{array}$ & $\begin{array}{l}\text { Bilateral inguinal, bilateral } \\
\text { axillary and mediastinal } \\
\text { lymph nodes }\end{array}$ & \\
\hline $10 / 2004$ & & $\begin{array}{l}\text { Partial penectomy and } \\
\text { urethrectomy and } \\
\text { superficial lymph node } \\
\text { dissection }\end{array}$ & pT2 N2 Mx Gx R0 V1 & \\
\hline $12 / 2004$ & & $\begin{array}{l}\text { Deep bilateral ilioinguinal } \\
\text { lymph node, external iliac } \\
\text { and obturator lymph } \\
\text { nodes dissection }\end{array}$ & $\begin{array}{l}\text { Left: } 1 / 10 \text { positive } \\
\text { inguinocrural lymph nodes; } \\
9 \text { iliac and obturator lymph } \\
\text { nodes with reactive changes } \\
\text { Right: } 13 \text { inguinocrural } \\
\text { lymph nodes and } 6 \text { external } \\
\text { iliac lymph nodes with } \\
\text { reactive changes }\end{array}$ & $\begin{array}{l}\text { Treatment of wound } \\
\text { infection and chronic } \\
\text { lymphedema }\end{array}$ \\
\hline $04 / 2005$ & & $\begin{array}{l}\text { PET-scan } \\
\text { Ultrasound } \\
\text { CT-scan }\end{array}$ & $\begin{array}{l}\text { Hepatic metastatic disease } \\
\text { in segment VIII }\end{array}$ & \\
\hline $05 / 2005$ & Weak urinary stream & $\begin{array}{l}\text { Cystourethroscopy } \\
\text { Urethral biopsy and } \\
\text { resection }\end{array}$ & $\begin{array}{l}\text { Relapse of malignant } \\
\text { melanoma in the urethra }\end{array}$ & \\
\hline $06 / 2005$ & None & Chemotherapy & & $\begin{array}{l}\text { Chemotherapy with } \\
\text { carboplatin (CDDP } 75 \\
\left.\mathrm{mg} / \mathrm{m}^{2}\right) \text { and deticene } \\
\left(\mathrm{DTC} 800 \mathrm{mg} / \mathrm{m}^{2}\right) \\
6 \text { cycles }\end{array}$ \\
\hline $07 / 2005$ & & CT-scan & $\begin{array}{l}\text { Reduction of liver } \\
\text { metastasis }\end{array}$ & \\
\hline $06 / 2006$ & & $\begin{array}{l}\text { Cerebral CT-scan } \\
\text { Cerebral MRI }\end{array}$ & Cerebral metastasis & \\
\hline Till 05/2007 & & & & $\begin{array}{l}\text { Chemotherapy with } \\
\text { fotemustine ( } 100 \\
\mathrm{mg} / \mathrm{m}^{2} \text { ) every } 3 \text { weeks }\end{array}$ \\
\hline $01 / 2007$ & & Cerebral MRI & $\begin{array}{l}\text { Reduction of cerebral } \\
\text { metastasis }\end{array}$ & \\
\hline $10 / 2007$ & & CT-scan & $\begin{array}{l}\text { Reduction of liver } \\
\text { metastasis }\end{array}$ & \\
\hline $03 / 2009$ & & Abdominal ultrasound & $\begin{array}{l}\text { Suspicious lesion of the } \\
\text { pancreas }\end{array}$ & \\
\hline $03 / 2009$ & & MRI of the abdomen & Negative & \\
\hline $05 / 2009$ & & PET-CT & No signs of recurrence & \\
\hline $08 / 2009$ & $\begin{array}{l}\text { Patient in good } \\
\text { general condition }\end{array}$ & & & $\begin{array}{l}\text { Conservative } \\
\text { treatment }\end{array}$ \\
\hline
\end{tabular}




\begin{tabular}{c|l|l|l}
$\begin{array}{c}\text { Case Reports in } \\
\text { Denmitolagy }\end{array}$ & $\begin{array}{l}\text { Case Rep Dermatol 2009;1:93-99 } \\
\text { D0I: } 10.1159 / 000256663\end{array}$ & Published online: November 20, 2009 & $\begin{array}{l}\text { O 2009 S. Karger AG, Basel } \\
\text { ISSN 1662-6567 } \\
\text { www.karger.com/cde }\end{array}$ \\
\hline
\end{tabular}

Fig. 1. Longitudinal section of the penis and the urethra.

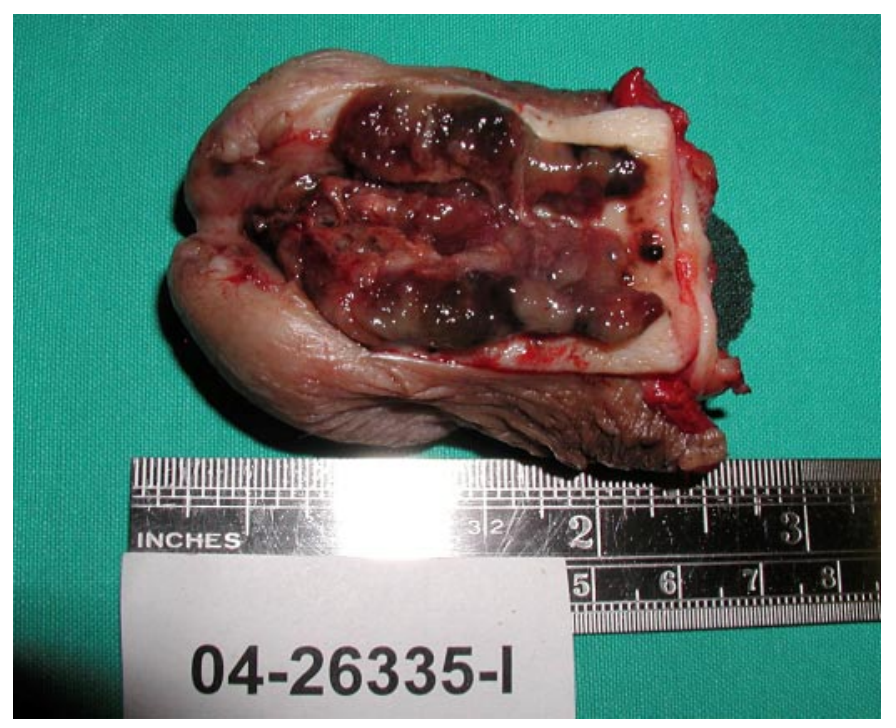

Fig. 2. Urethral epithelium with a malignant intraepithelial melanoma, in situ component, and malignant melanoma with tumor mass; melanocytic tumor cells are evidenced with the antibody anti-MelanA.

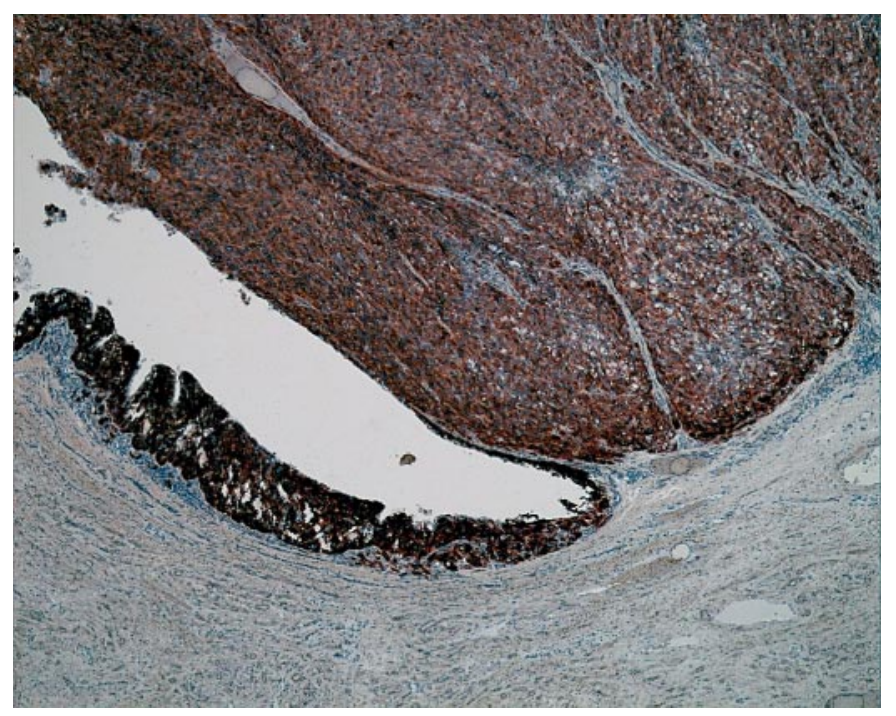


Fig. 3. External genitalia after partial penectomy and urethrectomy.

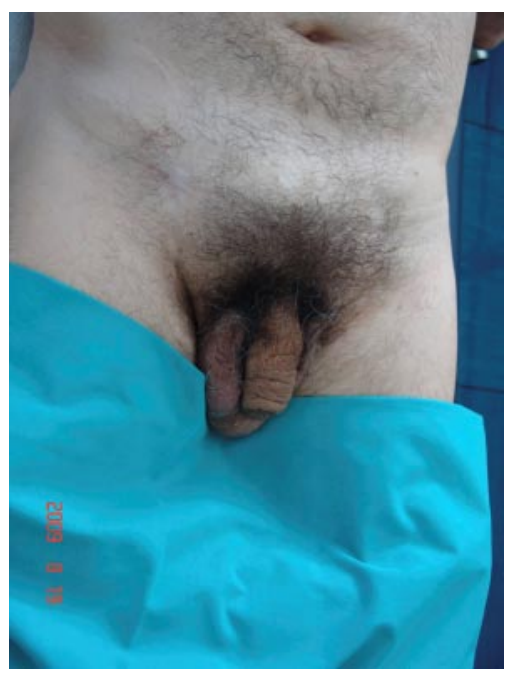




\section{References}

1 National Cancer Institute: SEER cancer statistics review 1975-2003 (01.01.2003). Available at: http://seer.cancer.gov/crs. Accessed September 15, 2006.

2 Sanchez-Ortiz R, Huang SF, Tamboli P, et al: Melanoma of the penis, scrotum and male urethra: a 40-year single institution experience. J Urol 2005;173:19581965.

-3 Van Geel AN, Den Bakker MA, Kirkels W, et al: Prognosis of primary mucosal penile melanoma: a series of 19 Dutch patients and 47 patients from the literature. Urology 2007;70:143-147.

4 Balch CM, Soong SJ, Gershenwald JE, et al: Prognostic factors analysis of 17,600 melanoma patients: validation of the American Joint Committee on Cancer melanoma staging system. J Clin Oncol 2007;7:87-97.

5 Nissenkorn I, Servadio C, Avidor I, Marshak G: Malignant melanoma of the female urethra. Urology 1987;29:562-565.

-6 Sugiyama VE, Chan JK, Kapp DS: Management of melanomas of the female genital tract. Curr Opin Oncol 2008;20:565-569.

7 Carroll PR, Dixon CM: Surgical anatomy of the male and female urethra. Urol Clin North Am 1992;19:339-346.

8 Oliva E, Quinn TR, Amin MB, et al: Primary malignant melanoma of the urethra: a clinic pathologic analysis of 15 cases. Am J Surg Pathol 2000;24:785-796.

-9 Batsakis JG, Suarey P: Mucosal melanomas: a review. Adv Anat Pathol 2000;7:167-180.

10 Yoshizawa T, Kawata N, Sato K, et al: Primary malignant melanoma of the female urethra. Urology 2007;70:1222.e13-1222.e16.

11 van Akkooi ACJ, Bouwhuis MG, et al: Morbidity and prognosis after therapeutic lymph node dissections for malignant melanoma. ELSO 2007;33:102-108.

12 Galliot-Repkat C, Cailliod R, Trost $\mathrm{O}$, et al: The prognostic impact of the extent of lymph node dissection in patients with stage III melanoma. Eur J Surg Oncol 2006;32:790-794.

13 Avril MF, Aamdal S, Grob JJ, et al: Fotemustine compared with dacarbazine in patients with disseminated malignant melanoma: a phase III study. J Clin Oncol 2004;22:1118-1125. 